\title{
RNAi-based conditional gene knockdown in mice using a I6 promoter driven vector
}

\author{
Vivek Shukla, Xavier Coumoul\# and Chu-Xia Deng \\ Genetics of Development and Disease Branch, 10/9N105, National Institute of Diabetes, Digestive and Kidney Diseases, \\ National Institutes of Health, Bethesda, Maryland, MD 20892, USA. \\ \# Present address: INSERM UMR-S 747, Unite de Pharmacologie, Toxicologie et Signalisation Cellulaire, Centre \\ Universitaire des Saints-Pères, 45 rue des Saints-Pères, 75270 Paris Cedex 06, FRANCE
}

Correspondence to: Chu-Xia Deng, Ph.D., Tel: (301) 402-7225; Fax: (301) 480-1135; Email: chuxiad@bdg10.niddk.nih.gov

Received: 2006.12.11; Accepted: 2007.01.05; Published: 2007.01.05

RNA interference (RNAi) is a powerful tool widely used for studying gene function in a number of species. We have previously developed an approach that allows conditional expression of a polymerase III promoter based small hairpin RNA (shRNA) in mice using the Cre-LoxP system. This approach uses a U6 promoter, which is inactive due to the presence of a ploxPneo cassette in the promoter; this promoter can be activated after excision of the neo gene in transgenic mice that express a Cre recombinase transgene. As a proof of principle, we have previously knocked down over $95 \%$ of Fgfr2 transcripts in mouse germlines, leading to embryonic lethality, while restricting the knockdown to the progress zone of the limb results in live animals with malformation of digits of both the forelimbs and hindlimbs. We now provide a detailed protocol, including a simplified single-step cloning procedure for vector construction. This method provides a fast yet efficient way to decipher gene functions in vivo in a tissue specific manner.

Key words: RNAi, shRNA, pol III vectors, transgenic mice, protocol

\section{Introduction}

RNA interference (RNAi) is a technique widely used to down-regulate the mRNA level of a specific gene. Small interfering RNAs (siRNAs) or small hairpin RNAs (shRNAs) are composed of a 22 ntdouble strand RNA sequence completely homologous to an unique target gene [1-6]. ShRNAs are generally produced by RNA polymerase II or III-based vectors while siRNA can be obtained from biotechnology companies. The siRNA or shRNA-expressing vectors are transfected into cell lines with classical lipotransfectants. The homology of sequence with a specific target gene allows formation of a complex comprising one strand of the shRNA or siRNA hybridized with the mRNA target and the RISC (RNAi-induced silencing complex) proteins in the cytoplasm. RISC then degrades the mRNA, which cannot be translated. The whole process leads to the specific downregulation of the RNA of the corresponding gene within 24-72 hours [2, 3, 7-9]. Because of the dominant feature of RNAi in causing cell lethality, several studies developed inducible regulation of RNAi in mammalian cells to achieved a controllable gene knockdown using either tetracycline, ecdysone, or tamoxifen-inducible systems $[8,10-13]$.

RNAi based gene knockdown has also been successfully used to study gene functions in mouse models [8, 14-21]. In some of these studies, shRNA constructs were first introduced into mouse embryonic stem (ES) cells through random integration [15, 22-24] or homologous recombination into the Rosa-26 locus [25]. The ES cells with ideal levels of gene knockdown were then injected into blastocysts to obtain mutant mice, following a standard approach for germline transmission used in gene targeting. In some other studies, the mutant mice were generated through a transgenic approach, i.e. injecting shRNA constructs directly into the pronucleus of the oocyte $[16,26,27]$. Mutant mice carrying modification of many genes, including Dnmt1, p53, Fgfr2, RasGAP, and WT1, have been generated using these approaches [22-24, 26, 28-30].

We have recently described a Cre-LoxP mediated shRNA approach that specifically knocks down the Fgfr2 gene with high efficiency (>90\% reduction of transcripts) in a tissue specific fashion [6]. This approach has several key features that may contribute to the high efficiency of temporal and spatial control of gene expression. First, the U6 promoter is used to ensure a ubiquitous and high level expression of short transcripts. Secondly, a ploxPneo is inserted into the U6 promoter between its proximal sequence element (PSE) and distal sequence element (DSE). The presence of the neo gene completely blocks transcriptional activity of the U6 promoter, therefore preventing any potentially lethal effect of the shRNA construct during the process of transgenic mice production. Lastly, our construct was introduced through pronuclear injection, making it relatively faster to generate mice than using ES cell based approaches.

This approach has several advantages compared with other in vivo approaches. First, because the neo gene is flanked by loxP sites, it can be deleted by Cre recombinase to restore the activity of the U6 promoter. Therefore, multiple studies investigating gene function in different tissues and different developmental stages can be performed after crossing the mutant mice with transgenic mice that express Cre in different tissues/organs. A recent study 
indicates that tissue specific gene knockdown can also be achieved by using tissue-specific polymerase-II (polII) promoter, which drives expression of a longer double strand RNA (dsRNA) expression unit [30]. Although effective, this approach is limited to a specific tissue and new transgenic mice carrying dsRNA driven by different tissue specific polII promoters need to be generated for each tissue of interest. Second, we chose to use pronuclear injection to generate mutant mice instead of using ES cells. This avoids the sophisticated ES cell manipulation that is required for germline transmission after the blastocyst injection. Thus, our approach should be technically easy and reliable. Finally, our approach does not require the construction of sophisticated gene-targeting vectors. Indeed, cloning the RNAi oligos into the shRNA expression vector has been simplified into a single step since our initial publications $[8,26]$, making it relatively simple and fast to generate mutant mice carrying an shRNA construct.

In this article, we present a detailed protocol to generate a U6-based shRNA construct and transgenic mice in order to share our approach with interested readers for their gene knockdown studies.

Figure 1. Maps of the two vectors used in the study. (A) pBS/U6-LoxP (active). (B) pBS/U6-ploxPneo (inactive, due to the presence of a ploxPneo gene that can be deleted by Cre recombination). The ploxPneo (1936 bp) is derived from the PGKneo [38] after adding loxP sites on both end of the PGK neo. Multiple cloning sites and their locations are indicated.

\section{A}

B

\section{Materials}

\section{Reagents}

DNA oligonucleotides

Distilled sterilized water $\left(\mathrm{dH}_{2} \mathrm{O}\right)$

TE buffer (10 mM Tris-Cl/1 mM EDTA, pH 7.4) $\mathrm{pH} 7.4)$

Low-TE buffer (1 mM Tris-Cl/0.1 mM EDTA,

ApaI, EcoRI, Sall, Not I, Asp 718, Afl III restriction enzymes (Roche)

DNA polymerase I, large fragment (Klenow)

(New England Biolabs)

T4 DNA polymerase (New England Biolabs)

MinElute Reaction Cleanup kit (Qiagen)

Qiaprep Spin Miniprep kit (Qiagen)

Dneasy kit (Qiagen)

LB media (Add the following to $800 \mathrm{ml} \mathrm{H}_{2} \mathrm{O}(10$ $\mathrm{g}$ Bacto-tryptone, $5 \mathrm{~g}$ yeast extract, $10 \mathrm{~g} \mathrm{NaCl}$ ). Adjust $\mathrm{pH}$ to 7.5 with $\mathrm{NaOH}$. Adjust volume to $1 \mathrm{~L}$ with $\mathrm{dH}_{2} \mathrm{O}$. Sterilize by autoclaving)

LB plates

(http://www.bbri.org/faculty/smith/LB Plates.html)

Ampicillin Stock (100 mg.ml-1) (3 g ampicillin

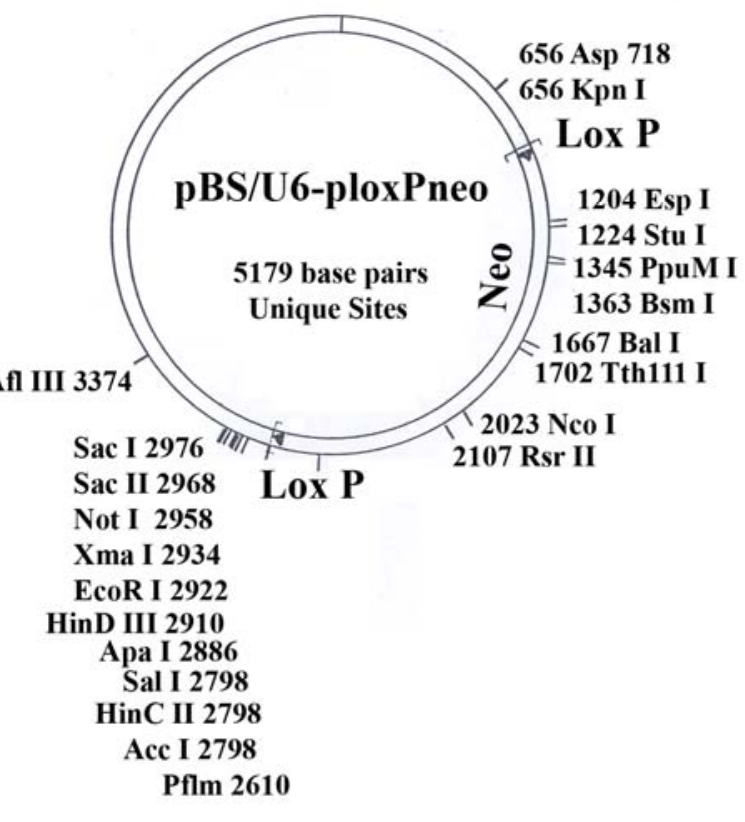

sodium salt (Fisher BP1760-25), add sterile water to raise volume to $30 \mathrm{ml}$. Filter sterilize through $0.22 \mu \mathrm{m}$ syringe filter. Aliquot into $1 \mathrm{ml}$ and store at $-20^{\circ} \mathrm{C}$ ).

Competent cells (DH5 $\alpha$, Invitrogen)

Ultra ${ }^{\mathrm{TM}}$ Phenol: Chloroform: Isoamyl Alcohol (Invitrogen, Cat No. 15593-031).

(Caution: these are chemical reagents with harmful effect)

RNA-Stat-60 reagent

Agarose powder (Gibco BRL, Invitrogen)

Ethidium bromide

QIAquick gel extraction kit

Nylon membrane (PROTRAN Plus from Scleicher \& Schuell)

Sheets of 3M Whatman Chromatography filter paper and saran wrap

$15 \%$ (wt/vol) polyacrylamide-8 $\mathrm{M}$ urea gel

Loading dye (contains $0.025 \%$ Bromophenol blue, $0.025 \%$ Xylene Cyanol, $0.5 \mathrm{mM}$ EDTA, $0.025 \%$ SDS) 161)

10X TBE (Quality Biological, Inc.; Cat \# 330-001-

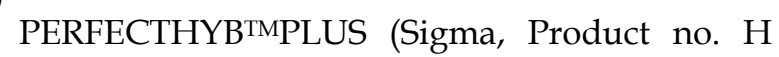


7033)

10X PNK buffer (Roche 1465492)

$\gamma 32 \mathrm{P}$ ATP (Amersham AA0068 $250 \mu \mathrm{Ci}$ ).

CAUTION: radioactive material. Manipulate under appropriate conditions 709557)

Poly Nucleotide Kinase (PNK) $(10 \mathrm{u} / \mu \mathrm{l}$, Roche

G25 column (Amersham 27- 5325-01)

Column 4K (X100)

161)

20X SSPE (Quality Biological, Inc.; Cat \# 330-015161)

20X SSC (Quality Biological, Inc.; Cat \# 330-003101)

20\% SDS (Quality Biological, Inc.; Cat \# 351-066-

dNTP: DNA polymerization mix is available at $20 \mathrm{mM} / \mathrm{dNTP}$ commercially; take $2 \mu \mathrm{l}$ of $20 \mathrm{mM} / \mathrm{dNTP}$ mix and make up the volume $100 \mu \mathrm{l}$ with $\mathrm{dH}_{2} \mathrm{O}$. It will give $400 \mu \mathrm{M} / \mathrm{dNTP}$ solution. CRITICAL: keep on ice during all the preparation of the reactions

Loading buffer: $12 \%$ FICOLL 400 by weight or $12 \%$ glycerol by volume; $60 \mathrm{mM} \mathrm{Na} 2 \mathrm{EDTA}, \mathrm{pH} 8$; $0.6 \%$ by weight SDS; $0.003 \%$ by weight bromphenol blue; $0.003 \%$ by weight xylene cyanol (for high molecular weight bands)

TAE 10X concentrated aqueous solution: TrisHcl 48.46 g/L (0,4 M), EDTA-Na,-salt 3.72 g/L (0.01 $\mathrm{M})$, Acetic acid $12.01 \mathrm{~g} / \mathrm{L}(0.2 \mathrm{M})$

pBS/U6-loxP and pBS/U6-ploxPneo vectors (Fig

1): The generation of these vectors from the original U6 promoter [31] was as described [8]. Both vectors are available upon request.

Lipofectamine (2000) (Invitrogen)

Cells -to-cDNA ${ }^{\mathrm{TM}}$ II kit (Ambion, Cat \# 1722,1723)

\section{Equipment}

Computer with internet access

Eppendorf tubes

Eppendorf Centrifuge (5415 D)

Heater

Floater

Beaker

Spectrophotometer (cuves)

Water bath

Shaker for bacteria suspensions

Bacteria plates incubator

Sterilized materials (toothpicks) for

transformation procedure

Ultraviolet transilluminator

Gene Amp PCR Systems 9700

Taqman PCR (Gene Choice)

Stratagene UV Crosslinker

Baker

Geiger counter

Cassette and phosphorimager screen

XCell IITM Blot Module

Hybridization oven

Poly Acrylamide Gel Electrophoresis (PAGE) apparatus
Animals

$\mathrm{FVB} / \mathrm{n}$ mice (Jackson lab) were used for generating transgenic mice.

\section{Reagent setup}

\section{Designing oligos}

With an internet browser, connect to http://www.ncbi.nlm.nih.gov/entrez/query.fcgi. Select in the Search tool bar « Nucleotide » and search for your mRNA or cDNA of interest throughout the Accession Number or name. Within the nucleotide sequence, select a region starting with one or two G (G or GG), followed by 19-20 bases to obtain a total of 20-21 nucleotides (nt) sequence and check that this whole sequence is $45-65 \%$ G/C. Finally, use a BLAST2 program (http://www.ebi.ac.uk/blast2/ for example) to check that the sequence is unique and has no significant homology with any other known ones. Additional information regarding nucleotides selection can be found in a recent publication [32].

Oligo 1: the native U6 promoter contains a (GGG), from which transcription is initiated. This motif is part of an ApaI restriction site (GGGCC/C). In the procedure, the ApaI site is cut and blunted, leaving only one $\mathrm{G}$ left at its $3^{\prime}$ end. The first strand of oligo 1 then contains one or two $G$ at the $5^{\prime}$ end which will be cloned at the ApaI site. An example of oligo 1 for Fgfr2 gene is shown in Fig. 2A. In this oligo, we added a HindIII site (AAGCTT), which serves as a 6base loop of the hairpin, in the oligo following the first 20-21 bp. The last part of the oligo is the complementary sequence of the 20-21 bp followed by three " $\mathrm{C}$ " corresponding to the complementary sequence of the first three " $\mathrm{G}$ ", five " $\mathrm{T}$ " corresponding to the termination site of the RNA polymerase III, and then one G, which will form an EcoRI site after annealing with oligo 2 .

Oligo 2 must be complementary to the Oligo 1 except for $4 \mathrm{nt}$ (AATT) that are added to the former's 5 ' end (Fig. 2B). This nt forms a digested EcoRI site (Fig. 2C), which will be used for cloning purposes. After transcription by U6 promoter, a hairpin structure will be formed in which the HindIII sequence form the head of the hairpin structure (Fig. 2D).

Note 1: We normally start with at least three candidate regions for the first oligo design so that the best sequence can be determined. Ensure that the designed oligos do not contain a (TTTTT) and a (AAAAA) motifs inside the 20-21 sequence. To avoid multiple inserts, do not order phosphorylated oligos. We ordered oligos from Operon Biotechnologies, although the source may not be critical.

Note 2: A recent study compared hairpin loops formed by several different sequences in cell culture condition. It was shown that the loop formed by "UUCAAGAGA" seems to have a higher efficiency than loops formed by other sequences [33], although its efficiency in vivo remains elusive. In this case, the nucleotide "TTCAAGAGA" can be used instead of "AAGCTT". 
Figure 2. An example of used oligos for shRNA vector. (A) Oligo 1 contains a two complementary sequences (in black) that can be formed upon shRNA transcription, a hairpin structure. A Hind III site forms the hairpin structure (see figure 2D in red). (B) Oligo 2 is complementary of oligo 1. Both oligos are designed against mouse Fgfr2. (C) Annealed Oligos 1 and 2. (D) Predicted hairpin structure with the corresponding colors (black: target sequence; red: Hind III site for hairpin).

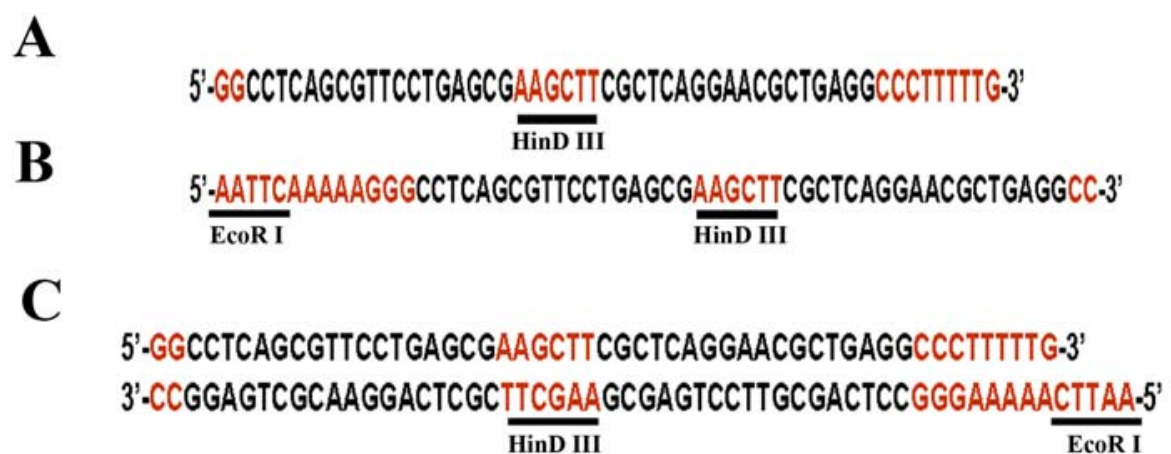

D

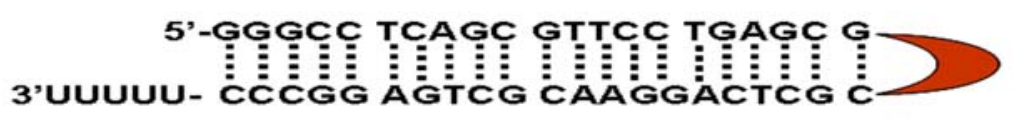

\section{Procedure}

\section{Annealing oligos}

a. Prepare a $0.2 \mu \mathrm{g} / \mu \mathrm{l}$ stock solution of each Oligo ( 1 and 2 , see Reagent Setup) with TE buffer.

b. Mix the components in an Eppendorf tube as shown in Table 1.

Table 1. Annealing oligos.

\begin{tabular}{|c|c|c|}
\hline Component & Amount & Final \\
\hline Ligation buffer $(10 \mathrm{X})$ & $4 \mu \mathrm{l}$ & $1 \mathrm{X}$ \\
\hline Oligo $1(0.2 \mu \mathrm{g} / \mu \mathrm{l})$ & $18 \mu \mathrm{l}$ & $0.09 \mu \mathrm{g} / \mu \mathrm{l}$ \\
\hline Oligo $2(0.2 \mu \mathrm{g} / \mu \mathrm{l})$ & $18 \mu \mathrm{l}$ & $0.09 \mu \mathrm{g} / \mu \mathrm{l}$ \\
\hline TOTAL & $40 \mu \mathrm{l}$ & \\
\hline
\end{tabular}

c. Heat $1 \mathrm{~L}$ of water in a beaker on a heater until the water reaches $70^{\circ} \mathrm{C}$.

d. Place the tube on a floater into the beaker and keep the tube at $70^{\circ} \mathrm{C}$ for 5 minutes.

e. Move the whole beaker onto the bench and let it cool down for 1 hour or until the water reaches room temperature. vector.

Subcloning the double-stranded oligo into the

\section{ApaI restriction of the vector.}

Mix the components in an eppendorf tube as shown in Table 2.

Table 2. ApaI restriction digestion of U6 vector.

\begin{tabular}{|c|c|c|}
\hline Component & Amount & Final \\
\hline pBS/U6-Neo vector & $5 \mu \mathrm{g}$ & $1 \mathrm{X}$ \\
\hline Buffer A (10X) & $2.5 \mu \mathrm{l}$ & 2 unit/ $\mu$ g of the \\
vector
\end{tabular}

Incubate at $30^{\circ} \mathrm{C}$ for 2 hours.

Check the digestion of the vector by running $1 \mu \mathrm{l}$ of the digestion mixture on $1 \%$ agarose gel.

Make sure the pBS/U6-Neo vector DNA is produced in a dam- bacteria strain to avoid methylation of the vector (ApaI is methylationsensitive).

4. Blunt the ApaI-digested DNA with T4 DNA polymerase or Klenow enzyme (which works with lower efficiency than T4 DNA polymerase).

The DNA was then Phenol-Chloroform extracted and resuspend in $10 \mu \mathrm{l}$ of Low-TE. Measure the DNA concentration. It should contain more than $2.5 \mu \mathrm{g}$ of DNA.

\section{EcoRI restriction.}

Add the reagents to an Eppendorf tube as shown in Table 3.

Table 3. EcoRI restriction digestion of the vector.

\begin{tabular}{|c|c|c|}
\hline Component & Amount & Final \\
\hline $\begin{array}{c}\text { ApaI digested and } \\
\text { blunted pBS/U6-neo } \\
\text { vector }\end{array}$ & $2.5 \mu \mathrm{g}$ & \\
\hline $\begin{array}{c}\text { Buffer } \mathrm{H}(10 \mathrm{X}) \\
\text { EcoRI }\end{array}$ & $1 \mu \mathrm{l}(10 \mathrm{unit})$ & $\begin{array}{c}4 \mathrm{unit} / \mu \mathrm{X} \text { of the } \\
\text { vector }\end{array}$ \\
\hline $\begin{array}{c}\text { TOTAL (make up } \\
\text { with } \mathrm{dH}_{2} \mathrm{O}\end{array}$ & $25 \mu \mathrm{l}$ & \\
\hline
\end{tabular}

Incubate at $37^{\circ} \mathrm{C}$ for 2 hours.

Purify the vector by Phenol-Chloroform extraction.

Resuspend the DNA in $20 \mu$ of TE. Measure DNA concentration.

6. Ligation of oligos-1/2 into the pBS/U6-Neo ApaI+EcoRI- digested vector.

a. Mix the components in an Eppendorf tube as shown in Table 4. 
Table 4. Ligation of oligos-1/2 into ApaI+EcoRI- digested U6 vector.

\begin{tabular}{|c|c|c|}
\hline $\begin{array}{c}\text { Component } \\
\text { ApaI+EcoRI- } \\
\text { digested pBS-U6- } \\
\text { Neo vector }\end{array}$ & Amount & Final \\
\hline $\begin{array}{c}\text { Annealed oligos } \\
\text { Ligation buffer }(10 \mathrm{X})\end{array}$ & $0.25 \mu \mathrm{l}$ & \\
\hline $\mathrm{T} 4 \mathrm{DNA}$ ligase & $2 \mu \mathrm{l}$ & $1 \mathrm{X}$ \\
\hline $\mathrm{dH}_{2} \mathrm{O}$ & $2 \mu \mathrm{l}$ & $1-2$ unit/reaction \\
\hline TOTAL & $14 \mu \mathrm{l}$ & \\
\hline
\end{tabular}
at $16^{\circ} \mathrm{C}$.

b. Centrifuge 10 seconds and incubate overnight

\section{Transformation}

a. Thaw competent cells $(100 \mu \mathrm{l})$ on ice.

b. Add 5 to $10 \mu$ l of the ligation mixture and mix gently by pipetting.

c. Incubate on ice for 30 minutes.

d. Heat shock for 45 seconds at $42^{\circ} \mathrm{C}$ and chill on ice for 5 minutes.

e. Add $0.9 \mathrm{ml}$ of room temperature LB media and incubate at $37^{\circ} \mathrm{C}$ for 1 hour in a shaker $(225 \mathrm{rpm})$.

f. Spread 100 to $300 \mu \mathrm{l}$ of the solution on LB plates containing ampicillin.

g. Incubate overnight at $37^{\circ} \mathrm{C}$.

8. Screen for colonies containing insert.

a. Pick 18 colonies from the LB plates with sterilized toothpicks and culture each colony in $2 \mathrm{~mL}$ of fresh LB media supplemented with ampicillin (100 $\left.\mu \mathrm{g} . \mathrm{ml}^{-1}\right)$ for overnight.

b. Using QIAprep Spin Miniprep Kit, or regular method for miniprep to purify the corresponding pBS/U6-Neo-shRNA vectors and dissolved in $20 \mu \mathrm{l}$ of TE.

c. Perform the restriction as shown in Table 5.

Table 5. Digestion of DNA using EcoRI + SalI.

\begin{tabular}{|c|c|c|}
\hline Component & Amount & Final \\
\hline DNA from miniprep & $2.0 \mu \mathrm{l}$ & \\
\hline EcoRI & $1 \mu \mathrm{l}$ & 10 unit/reaction \\
SalI & $1 \mu \mathrm{l}$ & 10 unit/reaction \\
\hline Buffer H & $2.5 \mu \mathrm{l}(10 \mathrm{X})$ & $1 \mathrm{X}$ \\
\hline TOTAL & $25 \mu \mathrm{l}$ & \\
\hline
\end{tabular}

A master mix can be made for 20 samples (without DNA), and $23 \mu$ aliquots should be divided into 19 Eppendorf tubes. Add $2 \mu$ of DNA extracted from each colony (a total of 18 colonies) into each Eppendorf tube. Also add $100 \mathrm{ng}$ of parent pBS-U6Neo DNA into the $19^{\text {th }}$ tube, which will be used as a control without insert.

d. Incubate at $37^{\circ} \mathrm{C}$ for 2 hours. Run the samples on a $3 \%$ agarose gel. The parent pBS-U6-Neo vector will release a $124 \mathrm{nt}$ fragment, while the DNA with one insert will release a $141 \mathrm{nt}$ fragment. The difference of $17 \mathrm{nt}$ is visible in the $3 \%$ agarose gel (Figure $3 \mathrm{~A})$.

Figure 3. Screening for the U6-Neo-RNAi vector containing the insert and its expression in mouse after deletion of the neo by EIIa-Cre transgene. (A) After double-strand oligo ligation into the pBS/U6-neo vector, check insertion by SalI and EcoRI restriction and migration in a 3\% agarose gel. Run two controls (parent and restricted parent vector) and an appropriate molecular weight marker (100, 150 and/or 200 bp). (B) Northern blot showing expression of pBSU6-NeoRNAi against mouse Fgfr2. Cre mediated deletion of the neo from U6-ploxPneo-Fgfr2 transgene allows expression of Fgfr2 RNAi. (C) Assessment of copy number of U6-ploxPneo-Fgfr2 transgene by realtime PCR using primers for neo gene. Control DNA with 1 copy and 2 copies of neo gene are from Sirt6+/- and Fgfr1-/- ES cells, respectively. (D) RTPCR analysis of Fgfr1-4 expression in E12.5 embryos of different genotypes. Wt: Wild type; U6: U6-ploxPneo-Fgfr2; Cre: EIIa-Cre; and U6;Cre: U6-Fgfr2;EIIa-Cre. The first row is a longer exposure of the second row. Three embryos for each genotype were shown. RT-PCR was performed using the following primers: Fgfr1-F: 5'TTCTGGGCTGTGCTGGTCAC-3', and Fgfr1-R: 5'-GCGAACCTTGTAGCCTCCAA-3'. Fgfr2-F: 5'AAGGTTTACAGCGATGCCCA-3', and Fgfr2-R: 5'-ACCACCATGCAGGCGATTAA-3'. Fgfr3-F: 5'CTAGTGTTCTGCGTGGCGGT-3', and Fgfr3-R: 5'-TTCTTATCCATTCGCTCCGG-3'. CTGTTGAGCATCTTTCAGGG-3', and Fgfr4-R: 5'-CGTGGAAGGCCTGTCCATCC-3'.
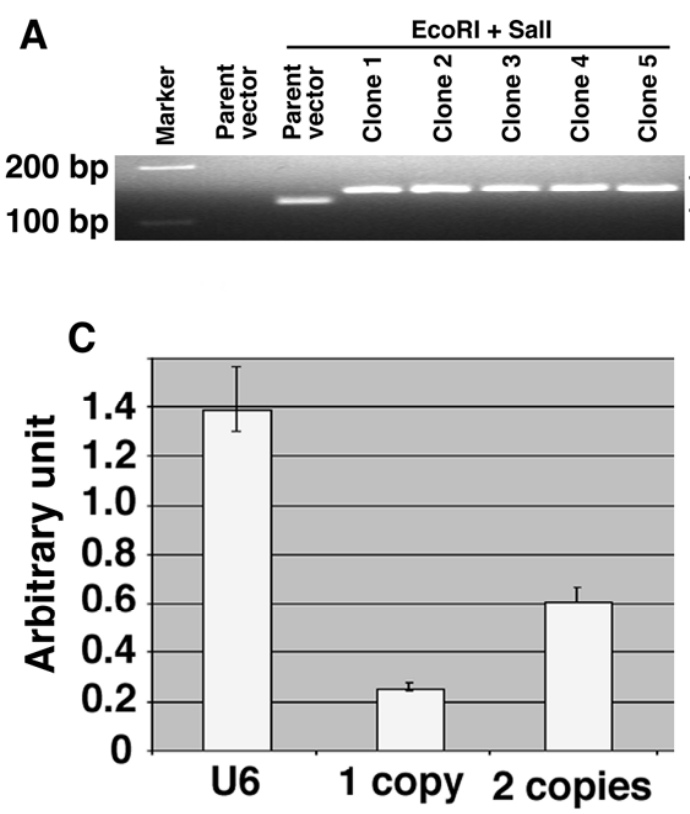

B

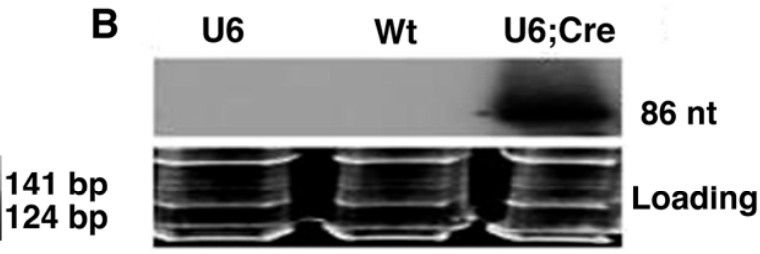

$141 \mathrm{bp}$ $124 \mathrm{bp}$
Fgfr4-F:

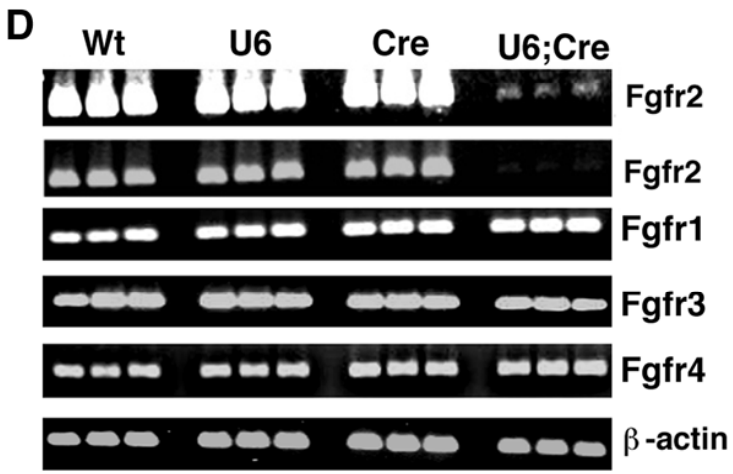




\section{Critical step}

1). The insert is $53 \mathrm{nt}$. Because ApaI+EcoRI digestion cuts away $36 \mathrm{nt}$ from the parent vector, the net gain with one insert is $17 \mathrm{nt}$.

2). In our original study by Coumoul et al. (2004)[8], we used two consecutive steps to clone a total of 4 shorter oligos (oligos 1-4) into the shRNA vector in order to avoid formation of hairpins of the oligos. We now found this is not necessary and only use a one-step protocol to introduce 2 longer oligos (oligos 1 and 2). If you encounter any trouble in using this one-step oligo cloning, a two-step cloning procedure can be used $[8,31]$.

\section{Sequencing the clones}

Once DNA vectors containing a single insert is confirmed, we send them to GENEWIZ, INC for sequencing using two primers. One primer (5'GCTATGACCATGATTACGCCA - 3') is located at 3017-3040, which is 131 bp away from ApaI (located at 2886). Another primer (T3 primer: 5' ATTAACCCTCACTAAAGGGA - 3') is located at 2992-3011, which is 106 bp away from ApaI. Both primers yield good sequencing.

\section{Checking the efficiency of the shRNA vector}

Because the presence of the ploxPneo cassette completely blocks the activity of the U6 promoter, it must be deleted by the Cre-loxP mediated recombination in cultured cells using one of the following procedures.

Option A describes a transient transfection procedure to delete the neo and should be used by researchers who consider a fast evaluation of gene knockdown. Option B describes a stable transfection and should be used when the fast evaluation procedure does not yield a clear result. Option C describes a convenient system to get shRNA vector and should be used by the labs, who do not have Cre recombinase system available. In all three procedures, the test should be performed in cells that express the target gene. Alternatively, a plasmid expressing the target gene needs to be co-transfected with shRNA expressing constructs.

Option A:

1) The U6-Neo-RNAi construct can be transfected into cultured cells bearing constitutively expressed Cre or inducible Cre using lipofectamine 2000 following a recommended procedure (http:/ / www.invitrogen.com/content/sfs/manuals/ lipofectamine2000_man.pdf). Parent U6-Neo vector without insert can be used as control.

2) After 48-72 hours of transfection, cells will be harvested and total RNA will be prepared using RNA STAT-60 (Tel-Test, Inc., Friendswood, TX) for RTPCR (Cells-to-cDNA TM II protocol for reverse transcription) analysis of target gene expression. RNAi knockdown is considered successful if about $70 \%$ of the mRNA target is degraded.

Option B:

1) The U6-Neo-RNAi construct can be transfected into regular cells followed by G418 selection.

2) Cells with a stable integrated U6-Neo-RNAi construct are then be transfected by Cre-expressing vector to delete the neo gene.

3) Alternatively, cells with inducible Cre can also be used for transfection. Cells with a stable integrated U6-Neo-RNAi construct are then placed in a Cre induction condition to delete the neo gene followed by RT-PCR analysis of target gene expression.

\section{Option C:}

For those laboratories where a Cre expression vector is not available, the shRNA vector can be generated in parallel by cloning the annealed oligo 1/2 (Step 2) into U6-RNAi vector (Fig. 1A). Because this vector does not contain the ploxPneo, the U6 promoter should be active when directly transfected into regular cells.

All above procedures work efficiently in our laboratory [8] and in the literature for assessing knockdown efficiency of vector based siRNAi expression.

\section{Generation of transgenic mice}

\section{Preparing vectors for pronuclear injection.}

The pBS/U6-Neo-shRNA vector is digested with Asp718 and AflIII according to the restriction procedure used in the previous paragraphs (see paragraph 4 and 6). After gel electrophoresis, we purify a 2739 bp fragment using the QIAquick Gel Extraction Kit (Qiagen, Valencia, CA). The fragment is resuspended in Low-TE buffer and adjusted to a final concentration of $2 \mathrm{ng} / \mu \mathrm{l}$ and injected into oocytes isolated from FVB/N mice through pronuclear injection. All animals are maintained and treated according to the approved NIH guidelines and techniques (http://www.nih.gov/science/models/mouse/sharing/5.html).

\section{Identifying $G_{0}$ transgenic founder mice and screening for germline transmission.}

a. Cut off $0.5 \mathrm{~cm}$ of the tails from weaned pups born to mothers carrying injected blastocysts and carry the tails in Eppendorf tubes. Isolate genomic DNA using Qiagen's Dneasy kit and proceed to genotyping according using PCR with the following pair of primers (5'-CGAAGTTATCTAGAGTCGAC-3', and 5'-AAACAAGGCTTTTCTCCAAGG-3') that amplifies $102 \mathrm{bp}$ from the U6 promoter and the connecting neo gene.

b. Amplify the template as shown in Table 6.

Table 6. PCR conditions for detecting the U6-neo transgene.

\begin{tabular}{|c|c|c|c|}
\hline $\begin{array}{c}\text { Cycle } \\
\text { number }\end{array}$ & Denaturation & Annealing & Polymerization \\
\hline 1 & 2 minutes at & & \\
\hline $2-34$ & $\begin{array}{c}10 \text { seconds at } \\
94^{\circ} \mathrm{C}\end{array}$ & $\begin{array}{l}20 \text { seconds at } \\
60^{\circ} \mathrm{C}\end{array}$ & $\begin{array}{c}30 \text { seconds at } \\
72^{\circ} \mathrm{C}\end{array}$ \\
\hline 35 & $\begin{array}{c}10 \text { seconds at } \\
94^{\circ} \mathrm{C}\end{array}$ & $\begin{array}{c}20 \text { seconds at } \\
60^{\circ} \mathrm{C}\end{array}$ & 10 minutes at \\
\hline
\end{tabular}

c. Run the PCR product in a $2.5 \%$ agarose gel to identify the positive $\mathrm{G}_{0}$ transgenic founder mice.

The PCR positive mice are candidate that carry the U6-Neo-RNAi transgene. These mice are crossed with wild type FVB/N mice to obtain germline transmission. The offspring mice containing the transgene are the F1 generation. 


\section{Generate U6-ploxPneo-RNAi/Cre mice.}

Because the presence of the ploxPneo in the RNAi vector that inactivate the U6 promoter activity, the F1 mice should be normal. To study the effect of RNAi mediated knockdown, the ploxPneo gene should be deleted. To achieve this, two independent strains of F1 mice carrying the U6-ploxPneo-RNAi transgene are crossed with mice carrying ubiquitously or tissue specifically expressed Cre transgene to create bigenic mice (U6-Neo-RNAi/Cre) that can be used for phenotypic analysis.

\section{Monitoring Cre-mediated recombination.}

The product generated by Cre-loxP mediated recombination in the U6-ploxPneo-RNAi/Cre bigenic mice can be visualized by using a primer pairs flanking the ploxPneo: 1: 5' CGCACAGACTTGTGGGAGAA-3'; and 2: 5'CACAATTACTTTACAGTTAG-3'. $1 \mu \mathrm{g}$ of DNA extracted from various tissues of bigenic mice can be used in the PCR reaction (as described in step 12).

\section{Determining U6-RNAi transgene expression.}

Because the transcript of the U6-RNAi transgene is very short, it can only be detected by Northern blot protocol that is optimized for short transcripts. A clear and sharp band can be obtained after 24-48 hour exposure (Fig. 3B). The following detailed northern protocol is optimized to detect processed small transcripts [26].

a. Mix $20 \mu \mathrm{g}$ RNA (volume of $15 \mu \mathrm{l}$ ) with $12 \mu \mathrm{l}$ of loading dye (contains $0.025 \%$ Bromophenol blue, 0.025\% Xylene Cyanol, o.5 mM EDTA, 0.025\% SDS). Heat samples in $90^{\circ} \mathrm{C}$ heat block for 5 minutes and then place it on ice. Load the samples onto $15 \%$ (wt/vol) polyacrylamide- $8 \mathrm{M}$ urea gel.

b. Run gel in 1X TBE running buffer at $200 \mathrm{~V}$ approximately 2-3 hrs or until bromophenol blue dye migrates above bottom of the gel.

c. Stain the gel with $4 \mu \mathrm{g} / \mathrm{ml} \mathrm{EtBr}$ in 0.5X TBE for $5 \mathrm{~min}$, and look for tRNA and 5S rRNA bands for quality of RNA prep and for loading control. Take digital snapshots of the gel and save images.

d. Set up transfer using XCell IITM Blot Module, (Invitrogen Cat No \# EI9051). Cut Nylon Membrane (PROTRAN Plus from Scleicher \& Schuell) and 8 sheets of 3M Whatman Chromatography filter paper to the size of the gel. Presoak membrane and filter paper in 0.5X TBE. It is important that both are thoroughly soaked. Place 4 pieces of soaked filter paper on top and 4 on the bottom, with the membrane underneath the gel. Transfer at constant current $(12 \mathrm{~V})$ for $1-2$ hours in $0.5 \mathrm{X}$ TBE.

e. While the blot is still moist (leave it on the wet 3MM support), UV crosslink with $1000 \mathrm{~mJ}$ of energy (Stratagene UV Crosslinker) RNA side up towards the lamps.

Pause point: Membrane can be wrapped and kept at room temperature for 2-3 days.

f. Prehybridize the membrane with PERFECTHYB TMPLUS (Sigma, Product no. H7033) in a hybridization oven and rotate at $42^{\circ} \mathrm{C}$ for $2-4$ hours.

g. Labeling probe as shown in Table 7.
Table 7. Label Oligo 1 with $\gamma$ 32P ATP.

\begin{tabular}{|c|c|c|}
\hline Component & Amount & Final \\
\hline Oligo 1 & $0.6-1 \mu \mathrm{l}$ & $50-100 \mathrm{ng}$ \\
$\begin{array}{c}\text { Polynucleotide kinase } \\
\text { buffer (10X) }\end{array}$ & $2 \mu \mathrm{l}$ & $1 \mathrm{X}$ \\
\hline $\begin{array}{c}\gamma \text { 32P ATP } \\
\text { Polynucleotide kinase }\end{array}$ & $6 \mu \mathrm{l}$ & $50-60 \mu$ Curie \\
\hline TOTAL & $1 \mu \mathrm{l}$ & 10 units \\
\hline
\end{tabular}

Incubate 30 minutes at $37^{\circ} \mathrm{C}$ and put on ice.

Pass through G25 column (Amersham 27- 532501) and check labeling efficiency (Column 4K (X100); Probe more than 5K (X100).

h. Hybridize the membrane at $42^{\circ} \mathrm{C}$ overnight with labeled probe in fresh hybridization buffer.

CRITICAL: Hybridization solution was used according to oligo size. For oligo less than 25 mer, $6 \mathrm{X}$ SSPE is used, while oligo longer than 25 mer, 5X SSPE should be used. Hybridization solution is comprised of SSPE ( $5 \mathrm{X}$ or $6 \mathrm{X}$ ), $5 \mathrm{X}$ Denharts, $0.5 \%$ SDS and carrier DNA 250-300 $\mu \mathrm{l}$ (from $10 \mathrm{mg} / \mathrm{ml}$ ) for $50 \mathrm{ml}$.

i. After the hybridization the membrane was washed with 6X SSPE, $0.1 \%$ SDS (add $300 \mathrm{ml}$ of 20X SSPE and $5 \mathrm{ml}$ of $20 \%$ SDS into $695 \mathrm{ml}$ of $\mathrm{dH}_{2} \mathrm{O}$ ) at $42^{\circ} \mathrm{C}$ for 10 minutes, and then washed with 2X SSC, $0.1 \%$ SDS (add $100 \mathrm{ml}$ of 20X SSC and $5 \mathrm{ml}$ of $20 \%$ SDS into $895 \mathrm{ml}$ of $\mathrm{dH}_{2} \mathrm{O}$ ) two times at $42^{\circ} \mathrm{C}$ for 10 minutes.

j. Drain and wrap in Saran Wrap and expose to $X$-ray film keeping the blot moist if it is not washed enough and need to be rewashed.

\section{Determine the copy number of the transgene}

Assessment of copy number of U6-ploxPneoFgfr 2 transgene by real-time PCR using primers (NeoU: 5' -AGAGGCTATTCGGCTATGACTG-3', and NeoD: 5'-GTGGCCAGCCACGATAGC-3') for neo gene. We used DNA extracted from Sirt6+/- and Fgfr1-/- ES cells as controls for 1 copy and 2 copies of neo gene, respectively. However, DNA extracted from any mouse cells carrying one copy and 2 copies of neo gene should be fine for this experiment. Relative copy of copies of transgene can be calculated against the known copy numbers (Fig. 3C).

\section{Determining expression levels of the target gene.}

Expression of the target gene can be evaluated by RT-PCR using RNA isolated from organs/tissues where Cre is expressed. Western blot analysis (Molecular Cloning protocol) can also be used if antibody is available. Efficiency of gene knockdown can be determined through comparing expression levels of the target gene between mutant and control mice. An example of Fgfr2 expression in the Fgfr2neo-RNAi/EIIa-Cre [34] mice analyzed by RT-PCR was shown in figure $3 \mathrm{D}$.

Sometimes RNAi may generate non-specific toxicity due to off-target effects. Much of the offtarget effects can be avoided by conducting a careful homology search in designing the first oligo to select sequences that are unique in the genome (Step 1). In addition, for targeted genes that belong to families containing highly related members, gene expression study should be performed to detect any possible alterations of these members. An example of gene expression of other three members of Fgf receptor 
family is shown in Fig. 3D.

\section{Troubleshooting}

As suggested in Table 8.

Table 8. Troubleshooting.

\begin{tabular}{|c|c|}
\hline Problems & Solution \\
\hline $\begin{array}{l}\text { Step 7, No colony after } \\
\text { transformation }\end{array}$ & $\begin{array}{l}\text { The ratio of insert to vector was not } \\
\text { adequate. In step } 3 \text {, the ratio of insert to } \\
\text { vector is } 40: 1 \text {. It can be varied from 10- } \\
100: 1 \text {. }\end{array}$ \\
\hline $\begin{array}{l}\text { Step } 8 \text {, No visible } \\
\text { difference of bands }\end{array}$ & $\begin{array}{c}\text { Always use at least } 3 \% \text { agarose gel and run } \\
\text { for } 2-3 \text { hrs at } 180 \mathrm{~V} \text {. }\end{array}$ \\
\hline $\begin{array}{l}\text { Step 9, Sequencing does } \\
\text { not work }\end{array}$ & $\begin{array}{l}\text { Sometimes, it is difficult to read through } \\
\text { the hairpin because of its strong secondary } \\
\text { structure. We have tried a few companies } \\
\text { and found Genewiz Inc. can read through } \\
\text { the hairpin structure with good results. }\end{array}$ \\
\hline $\begin{array}{l}\text { Step 10, No decreased } \\
\text { expression of the target } \\
\text { gene }\end{array}$ & $\begin{array}{l}\text { It can be caused by poor transfection } \\
\text { efficiency. Try to find an adequate } \\
\text { protocol for transfection. Another } \\
\text { possibility is that the RNAi oligo does } \\
\text { not work. If this is the case, new RNAi } \\
\text { oligo should be used. We normally start } \\
\text { with oligos against two different } \\
\text { regions of the target gene and rarely } \\
\text { found both do not work. }\end{array}$ \\
\hline
\end{tabular}

\section{Timeline}

Step 1-9: Two to four weeks.

Step 10: Two to four weeks.

Step 11: One to two months to generate transgenic founder mice.

Step 13-17: After chimera mice are generated, it takes about one to two more months to get F1 mice, and another two months before knockdown phenotypes can be examined from crosses of F1 mice with Cre expressing mice.

\section{Anticipated results}

Under our injection conditions (NIDDK Transgenic Core Facility), about $15 \%$ of the mice should be chimeras carrying the U6-Neo-RNAi transgene. After crossing with wild type FVB/N mice, more than $50 \%$ of the chimeric mice can pass the transgene in the first litter. Based on our expression studies on at least two strains, we show that transgenic mice carrying U6-Neo-Fgfr2RNAi constructs are normal, displaying Fgfr2 transcripts equivalent to those of wild-type controls (Fig. 3D), indicating that the $\mathrm{U} 6$ promoter is inactive in vivo due to the presence of the neo in the promoter. We were unable to detect expression of shRNA in those mice (Fig. 3B), suggesting that the presence of the ploxPneo gene inactivated the U6 promoter. Similar results have been recently shown by other studies [25, 35], although a neo gene with of smaller size (about $800 \mathrm{bp}$ ) is less tight in silencing U6 promoter activity [35] compared with the 1900 bp neo cassettes [8, 25, 26]. After excision of the neo through crossing with transgenic mice that express $\mathrm{Cre}$ in the mouse germline, the U6 promoter is re-activated, leading to over 95\% reduction of Fgfr 2 transcripts (Fig. 3D).

Like all other transgenic mice generated by pronuclear injection, the U6-Neo-shRNA construct randomly integrates into mouse genome. The levels of shRNA expression are likely to vary among transgenic lines due to integration sites and copy number. In Step 13, we crossed two independent F1 mice carrying the U6-ploxPneo-Fgfr2RNAi transgene with mice carrying Cre transgene to create bigenic mice (U6-Neo-Fgfr2RNAi/Cre) for assessing knockdown effects, and found that both strains showed similar phenotypes [26]. For those who intend to avoid potential expression variation due to position/copy number effects, the U6-NeoshRNA construct can be targeted into a known open chromosome locus with a single copy shown by $\mathrm{Yu}$ and McMahon (2006) [25]. On the other hand, phenotype variation is observed even in mice generated by gene targeting, suggesting that it is an intrinsic nature associated with the loss of function mutation, perhaps due to a different response of each individual to the assault. Actually, this could be beneficial in some circumstances where variable phenotypes may reveal new and unexpected information. For example, we and many others have purposely used sophisticated targeting modifications to generate hypomorphic alleles or isoform knockouts $[36,37]$. Thus, for those who intend to find strains with varying levels of target gene expression so that a series of "mutant allele" can be generated for a wild range of gene function analysis, more F1 strains need to be used in Step 13.

\section{Acknowledgment}

This work was supported by the intramural Research Program of National Institute of Diabetes, Digestive and Kidney Diseases, National Institutes of Health, USA.

\section{References}

1. Elbashir SM, Martinez J, Patkaniowska A, et al. Functional anatomy of siRNAs for mediating efficient RNAi in Drosophila melanogaster embryo lysate. Embo J 2001; 20: 6877-88.

2. Elbashir SM, Lendeckel $\mathrm{W}$, and Tuschl T. RNA interference is mediated by 21- and 22-nucleotide RNAs. Genes Dev 2001; 15 : 188-200.

3. Elbashir SM, Harborth J, Lendeckel W, et al. Duplexes of 21nucleotide RNAs mediate RNA interference in cultured mammalian cells. Nature 2001; 411: 494-8.

4. Collins RE, and Cheng X. Structural domains in RNAi. FEBS Lett 2005;579(26):5841-9

5. Rao M, and Sockanathan S. Molecular mechanisms of RNAi: implications for development and disease. Birth Defects Res C Embryo Today 2005; 75: 28-42.

6. Coumoul $X$, and Deng CX. RNAi in mice: a promising approach to decipher gene functions in vivo. Biochimie 2006;88(6):637-43.

7. Yu JY, DeRuiter SL, and Turner DL. RNA interference by expression of short-interfering RNAs and hairpin RNAs in mammalian cells. Proc Natl Acad Sci U S A 2002; 99: 6047-52.

8. Coumoul X, Li W, Wang RH, et al. Inducible suppression of Fgfr2 and Survivin in ES cells using a combination of the RNA interference (RNAi) and the Cre-LoxP system. Nucleic Acids Res 2004; 32: e85.

9. Novina CD, and Sharp PA. The RNAi revolution. Nature 2004; 430: 161-4.

10. Wang J, Tekle E, Oubrahim H, et al. Stable and controllable RNA interference: Investigating the physiological function of glutathionylated actin. Proc Natl Acad Sci U S A 2003; 100: 5103-6.

11. Czauderna F, Santel A, Hinz M, et al. Inducible shRNA expression for application in a prostate cancer mouse model. Nucleic Acids Res 2003; 31: e127.

12. Gupta S, Schoer RA, Egan JE, et al. Inducible, reversible, and stable RNA interference in mammalian cells. Proc Natl Acad Sci U S A 2004; 101: 1927-32.

13. Matsukura S, Jones PA, and Takai D. Establishment of conditional vectors for hairpin siRNA knockdowns. Nucleic Acids Res 2003; 31: e77. 
14. Hasuwa H, Kaseda K, Einarsdottir T, et al. Small interfering RNA and gene silencing in transgenic mice and rats. FEBS Lett 2002; 532: 227-30.

15. Rubinson DA, Dillon CP, Kwiatkowski AV, et al. A lentivirusbased system to functionally silence genes in primary mammalian cells, stem cells and transgenic mice by RNA interference. Nat Genet 2003; 33: 401-6.

16. Tiscornia $G$, Singer $O$, Ikawa $M$, et al. A general method for gene knockdown in mice by using lentiviral vectors expressing small interfering RNA. Proc Natl Acad Sci U S A 2003; 100: 1844-8.

17. Wiznerowicz $\mathrm{M}$, and Trono D. Conditional suppression of cellular genes: lentivirus vector-mediated drug-inducible RNA interference. J Virol 2003; 77: 8957-61.

18. Sarkar SN, and Das HK. Regulatory roles of presenilin-1 and nicastrin in neuronal differentiation during in vitro neurogenesis. J Neurochem 2003; 87: 333-43.

19. Miyagishi $M$, and Taira K. U6 promoter-driven siRNAs with four uridine $3^{\prime}$ overhangs efficiently suppress targeted gene expression in mammalian cells. Nat Biotechnol 2002; 20: 497500 .

20. Miyagishi M, and Taira K. Development and application of siRNA expression vector. Nucleic Acids Res Suppl 2002; (2): 113-4.

21. van de Wetering M, Oving I, Muncan V, et al. Specific inhibition of gene expression using a stably integrated, inducible small-interfering-RNA vector. EMBO Rep 2003; 4: 609-15.

22. Kunath $T$, Gish G, Lickert $H$, et al. Transgenic RNA interference in ES cell-derived embryos recapitulates a genetic null phenotype. Nat Biotechnol 2003; 21: 559-61.

23. Chang HS, Lin $\mathrm{CH}$, Chen $\mathrm{YC}$, et al. Using siRNA technique to generate transgenic animals with spatiotemporal and conditional gene knockdown. Am J Pathol 2004; 165: 1535-41.

24. Ventura A, Meissner A, Dillon CP, et al. Cre-lox-regulated conditional RNA interference from transgenes. Proc Natl Acad Sci U S A 2004; 101: 10380-5.

25. $\mathrm{Yu} \mathrm{J}$, and McMahon AP. Reproducible and inducible knockdown of gene expression in mice. Genesis 2006; 44: 252 61.

26. Coumoul X, Shukla V, Li C, et al. Conditional knockdown of Fgfr2 in mice using Cre-LoxP induced RNA interference. Nucleic Acids Res 2005; 33: e102.

27. Peng S, York JP, and Zhang P. A transgenic approach for RNA interference-based genetic screening in mice. Proc Natl Acad Sci U S A 2006; 103: 2252-6.

28. Stein P, Svoboda P, Anger M, et al. RNAi: mammalian oocytes do it without RNA-dependent RNA polymerase. Rna 2003; 9: 187-92.

29. Wianny F, and Zernicka-Goetz M. Specific interference with gene function by double-stranded RNA in early mouse development. Nat Cell Biol 2000; 2: 70-5.

30. Rao MK, Pham J, Imam JS, et al. Tissue-specific RNAi reveals that WT1 expression in nurse cells controls germ cell survival and spermatogenesis. Genes Dev 2006; 20: 147-52.

31. Sui G, Soohoo C, Affar el B, et al. A DNA vector-based RNAi technology to suppress gene expression in mammalian cells. Proc Natl Acad Sci U S A 2002; 99: 5515-20.

32. Cullen BR. Enhancing and confirming the specificity of RNAi experiments. Nat Methods 2006; 3: 677-81.

33. Brummelkamp TR, Bernards R, and Agami R. A system for stable expression of short interfering RNAs in mammalian cells Science 2002; 296: 550-3.

34. Lakso M, Pichel JG, Gorman JR, et al. Efficient in vivo manipulation of mouse genomic sequences at the zygote stage. Proc Natl Acad Sci U S A 1996; 93: 5860-5.

35. Xia X, Zhou H, Huang Y, et al. Allele-specific RNAi selectively silences mutant SOD1 and achieves significant therapeutic benefit in vivo. Neurobiol Dis 2006; 23: 578-86.

36. Xu X, Li C, Takahashi K, et al. Murine fibroblast growth factor receptor 1alpha isoforms mediate node regression and are essential for posterior mesoderm development. Dev Biol 1999;
208: 293-306.

37. Deng CX. Tumor formation in Brca1 conditional mutant mice. Environ Mol Mutagen 2002; 39: 171-7.

38. Tybulewicz VL, Crawford CE, Jackson PK, et al. Neonatal lethality and lymphopenia in mice with a homozygous disruption of the c-abl proto-oncogene. Cell 1991; 65: 1153-63. 